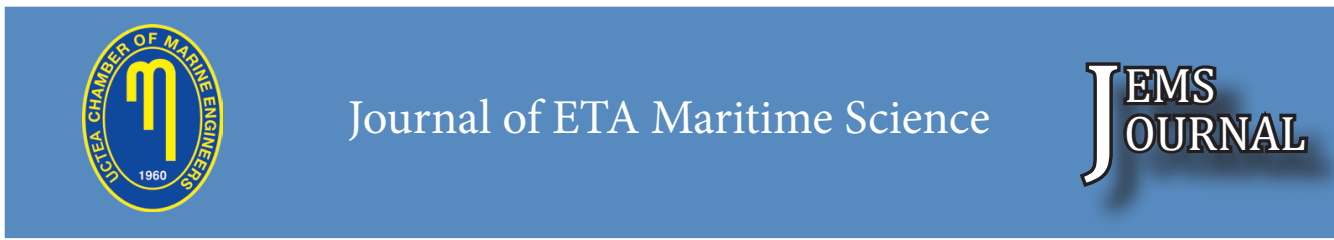

Corresponding Author: Burak ZINCİR

\title{
Assessment of Alternative Fuels from the Aspect of Shipboard Safety
}

\section{Burak ZINCİR, Cengiz DENIZ}

İstanbul Technical University, Maritime Faculty, Turkey

bzincir@itu.edu.tr; ORCID ID: https://orcid.org/0000-0002-6719-4730

denizc@itu.edu.tr; ORCID ID: https://orcid.org/0000-0001-9702-4583

\begin{abstract}
Global regulations about shipboard emissions become stricter day by day. There are various ways to reduce shipboard emissions, and using alternative fuels on main engine and auxiliary engines is one of these ways. The alternative fuels can have different physicochemical properties than conventional fuels, which needs special procedures and safety precautions while using onboard. Safety is important term for sustainable shipping. This study aimed to determine the safety ranking of the trend alternative fuels and possible ones in the future. A safety evaluation method was formed to assess fourteen alternative fuels by considering handling, storage and crew health. Flashpoint, auto-ignition, explosion limits, flame speed, density, and exposure limit are criteria for the safety evaluation. Analytic Hierarchy Process was used while finding the weighing of the alternative fuels at these criteria. Scale of relative importance was used to find the pair-wise comparison of the fuels. The criteria weighing were determined by taking expert opinions. Seven experts gave points to the criteria at the asked questionnaire. The questionairre was about; which fuel property is more important at the storage, handling, and operation with the fuels. According to the final safety assessment results, liquefied petroleum gas had the highest weighing of 0,130. Ethanol and ammonia followed it with 0,120 and 0,116, respectively. Liquefied natural gas and methanol, as trend alternative fuels with liquefied natural gas for shipping industry, got 0,084 and 0,053 , respectively.
\end{abstract}

Keywords: Alternative fuels, Shipboard safety, Safety assessment.

\section{Alternatif Yakıtların Gemi Emniyeti Açısından Değerlendirilmesi}

\section{$\ddot{O} z$}

Gemi kaynaklı emisyonları ilgilendiren uluslar arası denizcilik sözleșmeleri gün geçtikçe katılaşmaktadır. Gemi kaynaklı emisyonları azaltmaya yönelik çeșitli yöntemler bulunmaktadır ve alternatif yakıt kullanımı da bunlardan biridir. Alternatif yakıtların, gemilerde kullanılan konvansiyonel yakıtlardan farklı fiziko-kimyasal özellikleri olabilir. Bu farklı özellikler, gemi üzerinde özel prosedürler ve emniyet tedbirleri alınmasını gerektirebilir. Emniyet, sürdürülebilir deniz ticareti için önemli bir kavramdır. Bu çalışma günümüzde revaçta olan alternatif yakıtların ve ileride kullanılabilecek olanların emniyet puanını belirlemeyi amaçlamaktadır. Emniyet değerlendirme yöntemi oluşturularak, seçilen 14 alternatif yakıt, depolama, elleçleme ve mürettebat sağlı̆̆ı temel alınarak değerlendirilmiștir. Emniyet değerlendirmesinde kullanılan değerlendirme kriterleri, parlama noktası, kendiliğinden tutuşma sıcaklığı, patlama limitleri, alev hızı, yoğunluk ve etkileme derecesidir. Analitik Hiyerarşi Prosesi 
kullanılarak bu değerlendirme yapılmıştır. Nispi önem derecesi puanları kullanılarak yakıtların çiftsel karşılaştırması yapılmıştır. Kriterlerin ağırlıkları da yedi ekspere sorulan anket sonucunda görüşleri alınarak belirlenmiştir. Anket, hangi yakıt özelliğinin, yakıtların depolanması, elleçlenmesi ve operasyonunda daha önemli olduğunu sormaktadır. Çalışma sonuçlarına göre sıvilaştırılmış petrol gazı 0,130 ile en yüksek emniyet puanını almıștır. Etanol ve amonyak, 0,120 ve 0,116 ile takip etmiştir. Günümüzün revaçta alternatif yakılarından sıvılaştırılmış doğalgaz ve metanol, 0,084 ve 0,053 emniyet puanı almıştır.

Anahtar Kelimeler: Alternatif yakıtlar, Gemi emniyeti, Emniyet değerlendirmesi.

\section{Introduction}

Because of strict emission regulations and reduction at shipboard emission limits, alternative fuel usage on ships increases. Nowadays, liquefied natural gas (LNG), methanol and liquefied petroleum gas (LPG) are used as alternative fuels as sole fuel or dual-fuel with conventional fuels. While using these fuels on ships, special procedures and safety precautions have to be taken, because they have different fuel properties than the conventional fuels.

The safety term is important for the shipping industry, and is considered as one of the pathways for sustainable shipping. The safety is defined as 'The absence of unacceptable levels of risk to life, limb, and health (from non-willful acts)' by International Maritime Organization [1]. All shipboard operations are done by taking the safety into consideration according to International Convention for Safety of Life at Sea (SOLAS) which was entered into force on 25 May 1980. The SOLAS includes minimum standards for construction, equipment of ship, and shipboard operations to provide safe voyage of ships [2]. It is sure that the safety is the most important issue at the alternative fuel use on ships. The International Code of Safety for Ships using Gases or other Lowflashpoint Fuels was entered into force on 1 January 2017, which aims to provide minimum safety standards for ships using alternative fuels to reduce risk to the ship, crew, and environment, by the amendments to the SOLAS [3].

Researchers also focus on the safety of various alternative fuels. A previous research was done about the assessment of methanol, ethanol, LNG, and hydrogen at various criteria, which the safety was one of the criteria [4]. The study briefly mentioned about the safety aspects of these fuels, and compared them by using Analytic Hierarchy Process (AHP). Density, flammability limits and combustion characteristics of the alternative fuels were used to give point to each fuel. Another study was done by $\mathrm{Gu}$ and Zhang [5]. They compared LNG, nuclear power, wind energy, solar energy, and bio-fuel by the AHP at various criteria, one of them was again the safety. Mansson [6], conducted a study about the comparison of LNG, two types of methanol and hydrogen produced from electrolysis by wind power at the safety and other 9 criteria by using the AHP. He used fire \& explosion characteristics, flashpoint and health effect of the alternative fuels at his safety assessment. Although there are some studies about the safety assessment of the alternative fuels, it takes small place at the whole assessment study. It does not directly focus on the safety aspect of the alternative fuels in detail, and the studies assess few numbers of alternative fuels.

This study aims to focus on the safety aspect of higher number of alternative fuels in detail by focusing on shipboard handling, storage and crew health. The study showed that, LPG had the highest final safety weighing of 0,130. Ethanol, ammonia, LNG, and methanol had $0,120,0,116,0,084$, and 0,053 , respectively, as final safety weighing. Remaining alternative fuels had lower final 
safety weighing than above-mentioned fuels. The lower final safety weighing points out the higher safety precaution demand while storage and operation onboard of these alternative fuels.

\section{Alternative Fuels}

Using alternative fuel on diesel engines is one of the emission abatement methods. Sulfur free or lower sulfured alternative fuels reduce sulfur oxide $\left(\mathrm{SO}_{\mathrm{X}}\right)$ emissions. Combustion specifications of these fuels can mitigate nitrogen oxide $\left(\mathrm{NO}_{\mathrm{X}}\right)$, and $\mathrm{CO}_{2}$ emissions. The alternative fuels were started to be used at shore-based facilities for many years before. Rudolf Diesel tested his first engines with peanut oil over 100 years ago [7]. On the contrary, it is in development at the shipping industry, and it starts to increase in recent years.

The alternative fuels, which were used at this study, had to be determined. For this purpose, the literature search is done both at Web of Science and Google Scholar with the keywords, diesel engine and alternative fuels. Since Web of Science gave a limited number of studies, the Google Scholar results were selected in this study. There are many studies examining various alternative fuels on the diesel engines, but the significant study number is important. Found alternative fuels were again searched at the Google Scholar with the same keywords, and the exact study numbers were detected.

The alternative fuel number was 37, and the total paper number at the Google Scholar about the alternative fuel use on diesel engines was 581.414 [8]. As a significant study number, 15000, which was equal about to $2,5 \%$ of the total researches, was determined. As a result, the number of 14 alternative fuels was selected, because they were above the significant study number. Hydrogen (78.400), ethanol (47.200), methanol (43.300), waste cooking oil (32.700), palm oil (28.200), corn oil
(27.300), ammonia (24.700), pyrolysis oil (22.600), kerosene (22.000), rapeseed oil (20.600), soybean oil (20.500), LPG (19.600), LNG (19.500) and jatropha oil (16.000) had the research numbers above from 15000 .

\section{Comparison Criteria for Safety Assessment}

The previous studies in the literature used flammability, toxicity, fire \& explosion risks, density, auto-ignition temperature, stoichiometric air-fuel ratio, octane and cetane numbers of the alternative fuels as the comparison criteria for the safety assessment [4 - 6]. In this study, flashpoint, auto-ignition temperature, flammability limits, flame speed, density, and exposure limit of each alternative fuel were taken into consideration when forming the safety assessment method for mentioned alternative fuels. Table 1 shows specifications of the alternative fuels.

The flashpoint is the lowest temperature which vapor of the material will ignite by the support of an ignition source [47]. The flashpoint of a fuel is important at the storage and handling because lower flashpoint temperature means fuel is more dangerous. The intention of fuel to ignite by outside sources such as sparks, arc etc. is higher if the flashpoint temperature is lower.

The auto-ignition temperature is a limit, which a material will ignite without the support of an ignition source [48]. If the auto-ignition temperature of a fuel is high, its resistance to spontaneous ignition is higher. It means it is easier to store and handle these kinds of fuels in the tanks.

Combustible materials are able to burn within the lower and upper fuel limits which are determined experimentally. These limits are considered as the flammability limits or explosive limits. There is a lower explosive limit (LEL), which is the lowest limit of fuel concentration in the combustible mixture 
Table 1. Specifications of the Alternative Fuels

\begin{tabular}{|c|c|c|c|c|c|c|}
\hline $\begin{array}{l}\text { Alternative } \\
\text { Fuels }\end{array}$ & $\begin{array}{c}\text { Flashpoint } \\
\left({ }^{\circ} \mathrm{C}\right)\end{array}$ & $\begin{array}{c}\text { Auto- } \\
\text { ignition }\left({ }^{\circ} \mathrm{C}\right)\end{array}$ & $\begin{array}{l}\text { Density } \\
\left(\mathrm{kg} / \mathrm{m}^{3}\right)\end{array}$ & $\begin{array}{c}\text { Flammability } \\
\text { Limits } \\
(\%)\end{array}$ & $\begin{array}{c}\text { Flame Speed } \\
(\mathrm{cm} / \mathrm{s})\end{array}$ & $\begin{array}{c}\text { Exposure } \\
\text { Limit (mg/ } \\
\left.\mathrm{m}^{3}-8 \mathrm{~h}\right) \\
\end{array}$ \\
\hline Ammonia & $\begin{array}{l}132 \\
{[9]} \\
\end{array}$ & $\begin{array}{c}650 \\
{[10,11]} \\
\end{array}$ & $\begin{array}{c}682 \\
{[10,11]} \\
\end{array}$ & $\begin{array}{c}15-25 \\
{[9]} \\
\end{array}$ & $\begin{array}{c}14 \\
{[12]}\end{array}$ & $\begin{array}{c}17 \\
{[11]} \\
\end{array}$ \\
\hline Corn Oil & $\begin{array}{c}277 \\
{[13,14]}\end{array}$ & $\begin{array}{c}393 \\
{[15,16]}\end{array}$ & $\begin{array}{c}916 \\
{[14,15]}\end{array}$ & Unknown & Unknown & $\begin{array}{c}10 \\
{[16]}\end{array}$ \\
\hline Ethanol & $\begin{array}{c}13 \\
{[4,17,18]} \\
\end{array}$ & $\begin{array}{c}363 \\
{[4,18]}\end{array}$ & $\begin{array}{c}794 \\
{[4,17]} \\
\end{array}$ & $\begin{array}{c}3,3-19 \\
{[4]}\end{array}$ & $\begin{array}{l}41 \\
{[4]} \\
\end{array}$ & $\begin{array}{c}1900 \\
{[19]} \\
\end{array}$ \\
\hline Hydrogen & $\begin{array}{c}-150 \\
{[4]}\end{array}$ & $\begin{array}{c}585 \\
{[4,20]}\end{array}$ & $\begin{array}{c}83,8 \\
{[4,20]}\end{array}$ & $\begin{array}{c}4-75 \\
{[4]}\end{array}$ & $\begin{array}{c}270 \\
{[4,20]}\end{array}$ & $\begin{array}{l}336 \\
{[21]}\end{array}$ \\
\hline Jatropha Oil & $\begin{array}{c}240 \\
{[13,14]}\end{array}$ & $\begin{array}{l}274 \\
{[22]}\end{array}$ & $\begin{array}{c}920 \\
{[13,14]}\end{array}$ & Unknown & Unknown & 10 \\
\hline Kerosene & $\begin{array}{c}38 \\
{[23,24,25]}\end{array}$ & $\begin{array}{c}210 \\
{[23,25]}\end{array}$ & $\begin{array}{l}775 \\
{[23]}\end{array}$ & $\begin{array}{c}0,7-7 \\
{[23]}\end{array}$ & $\begin{array}{c}60 \\
{[26]}\end{array}$ & $\begin{array}{l}200 \\
{[25]}\end{array}$ \\
\hline LNG & $\begin{array}{r}-188 \\
{[27]}\end{array}$ & $\begin{array}{c}537 \\
{[4,28]}\end{array}$ & $\begin{array}{l}450 \\
{[4]}\end{array}$ & $\begin{array}{c}5-15 \\
{[28]}\end{array}$ & $\begin{array}{l}38 \\
{[4]}\end{array}$ & $\begin{array}{l}650 \\
{[28]}\end{array}$ \\
\hline LPG & $\begin{array}{c}-105 \\
{[29,30]}\end{array}$ & $\begin{array}{l}450 \\
{[29]}\end{array}$ & $\begin{array}{l}540 \\
{[31]}\end{array}$ & $\begin{array}{c}2-10 \\
{[29,30]}\end{array}$ & $\begin{array}{c}40 \\
{[32]}\end{array}$ & $\begin{array}{c}1900 \\
{[29,30]}\end{array}$ \\
\hline Methanol & $\begin{array}{c}12 \\
{[33]}\end{array}$ & $\begin{array}{l}470 \\
{[4]} \\
\end{array}$ & $\begin{array}{l}682 \\
{[4]} \\
\end{array}$ & $\begin{array}{c}6-36,5 \\
{[4,33]} \\
\end{array}$ & $\begin{array}{l}50 \\
{[4]} \\
\end{array}$ & $\begin{array}{l}196 \\
{[33]} \\
\end{array}$ \\
\hline Palm Oil & $\begin{array}{l}280 \\
{[14]} \\
\end{array}$ & $\begin{array}{l}316 \\
{[34]}\end{array}$ & $\begin{array}{l}952 \\
{[34]}\end{array}$ & Unknown & $\begin{array}{c}83 \\
{[35]} \\
\end{array}$ & 10 \\
\hline Pyrolysis Oil & $\begin{array}{l}104 \\
{[36]}\end{array}$ & $\begin{array}{l}348 \\
{[36]}\end{array}$ & $\begin{array}{c}1.200 \\
{[37]} \\
\end{array}$ & $\begin{array}{c}0,9-5,9 \\
{[38]} \\
\end{array}$ & Unknown & $\begin{array}{c}52 \\
{[36]} \\
\end{array}$ \\
\hline Rapeseed Oil & $\begin{array}{c}317 \\
{[14,39]}\end{array}$ & $\begin{array}{l}360 \\
{[40]}\end{array}$ & $\begin{array}{r}910 \\
{[14]} \\
\end{array}$ & Unknown & Unknown & $\begin{array}{c}10 \\
{[39]}\end{array}$ \\
\hline Soybean Oil & $\begin{array}{c}282 \\
{[41]} \\
\end{array}$ & $\begin{array}{l}445 \\
{[41]}\end{array}$ & $\begin{array}{r}920 \\
{[14]} \\
\end{array}$ & Unknown & $\begin{array}{c}94 \\
{[42]} \\
\end{array}$ & $\begin{array}{c}10 \\
{[43,44]}\end{array}$ \\
\hline $\begin{array}{l}\text { Waste } \\
\text { Cooking Oil }\end{array}$ & $\begin{array}{l}278 \\
{[45]}\end{array}$ & $\begin{array}{c}300 \\
{[40,46]}\end{array}$ & $\begin{array}{l}910 \\
{[45]}\end{array}$ & Unknown & Unknown & 10 \\
\hline
\end{tabular}

to be burn, and upper explosive limit (UEL), which is the highest limit of fuel concentration in the combustible mixture to be burn [49]. If the flammability limit of a fuel is wide, it means it can be burned at more variety of proportion of mixture, and it needs more precautions at the storage and handling operations.

The flame speed is the rate of spreading of the flame during the combustion process [50]. If the flame speed is high, it is more difficult to extinguish the flames, and it spreads quickly. The flame speed is another important factor in storage and handling operations.
The density is the mass per unitvolume of a fuel. The fuels with higher density remain one part of the room while tank leakage, in contrary the fuels with low density expand more quickly, and ventilation of a room is easier.

The exposure limit is the highest permissible limit to airborne concentrations of chemical substances which workers are exposed daily. Threshold Limit Values (TLV) are taken into consideration at this safety evaluation method. These values are developed as guidelines to assist in preventing health hazards at work places, and they are not legal standards [51]. The 
exposure rate of jatropha oil, palm oil and waste cooking oil (WCO) could not be found in the literature, thus it is assumed that they have same exposure rate with other vegetable oils.

\section{Safety Assessment Method}

The safety assessment was done with the assist of the Analytic Hierarchy Process (AHP), which was found by Saaty [52]. The AHP is a powerful decision-making tool for complex, multi-criteria problems. It is useful if data are both quantitative and qualitative or criteria weights are given referred to expert opinions [53]. More detailed information can be found in Saaty's study.

In this study, flashpoint, auto-ignition temperature, flammability limits, flame speed, density, and exposure limit of fuels were compared. To determine the importance of criteria at the storage and handling operations, expert opinions were taken. The experts were experienced academicians who worked at the ships for many years.

Data in Table 1 were used at the AHP to find weighing of the alternative fuels. Value difference between each alternative fuel forms intervals for scale of relative importance points, which were used at the AHP [4]. To form a single pair-wise comparison matrix, scale of relative importance was used to determine which item is more important than the other. Table 2 shows the alternative fuel notations, Table 3 shows the scale of relative importance for AHP, and Figure 1 illustrates the safety evaluation diagram.

Table 2. Alternative Fuel Notations for Assessment

\begin{tabular}{|l|c|}
\hline Alternative Fuels & Alternative Notation \\
\hline Ammonia & A1 \\
\hline Con Oil & A2 \\
\hline Ethanol & A3 \\
\hline Hydrogen & A4 \\
\hline Jatropha Oil & A5 \\
\hline Kerosene & A6 \\
\hline LNG & A7 \\
\hline LPG & A8 \\
\hline Methanol & A9 \\
\hline Palm Oil & A10 \\
\hline Pyrolysis Oil & A11 \\
\hline Rapeseed Oil & A12 \\
\hline Soybean Oil & A13 \\
\hline WCO & A14 \\
\hline
\end{tabular}

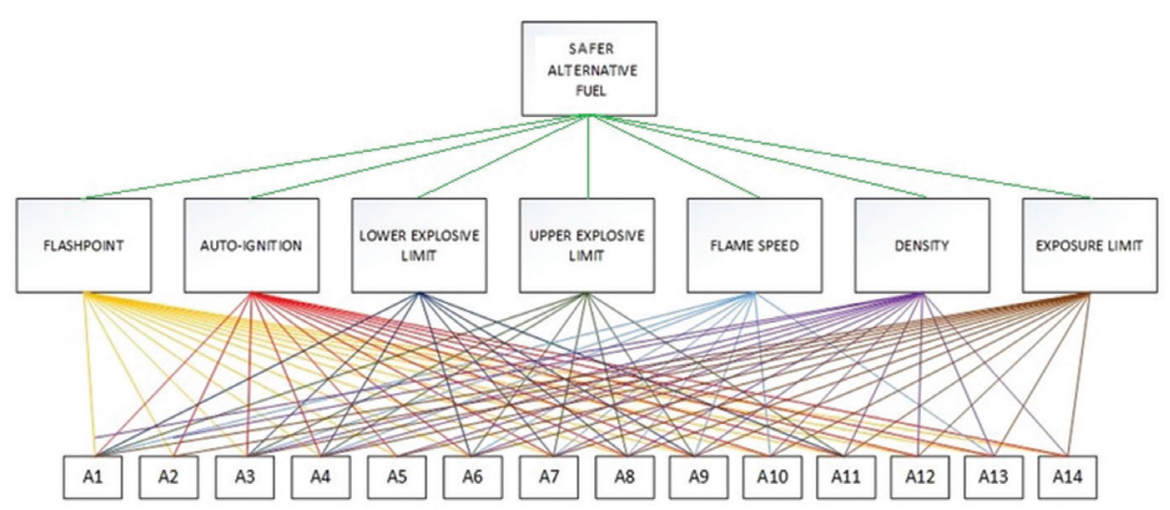

Figure 1. Safety Evaluation Diagram 
Table 3. Scale of Relative Importance [54]

\begin{tabular}{|l|l|l|}
\hline Scales & Definition & Note \\
\hline 1 & Equal importance & i is equally important to $\mathrm{j}$ \\
\hline 3 & Moderate importance & i is moderately important to $\mathrm{j}$ \\
\hline 5 & Essential importance & i is essentially important to $\mathrm{j}$ \\
\hline 7 & Very strong importance & i is very strongly important to $\mathrm{j}$ \\
\hline 9 & Absolute importance & i is very absolutely important to $\mathrm{j}$ \\
\hline $2,4,6,8$ & Intermediate value & $\begin{array}{l}\text { The relative importance of } \mathrm{i} \text { is between to } \\
\text { adjacent judgment }\end{array}$ \\
\hline
\end{tabular}

Table 4. Random Index Values [56]

\begin{tabular}{|c|c|c|c|c|c|c|c|c|c|c|c|c|c|}
\hline Order & $\mathbf{2}$ & $\mathbf{3}$ & $\mathbf{4}$ & $\mathbf{5}$ & $\mathbf{6}$ & $\mathbf{7}$ & $\mathbf{8}$ & $\mathbf{9}$ & $\mathbf{1 0}$ & $\mathbf{1 1}$ & $\mathbf{1 2}$ & $\mathbf{1 3}$ & $\mathbf{1 4}$ \\
\hline $\begin{array}{c}\text { Random } \\
\text { Index (RI) }\end{array}$ & 0 & 0,52 & 0,89 & 1,11 & 1,25 & 1,35 & 1,40 & 1,45 & 1,49 & 1,52 & 1,54 & 1,56 & 1,58 \\
\hline
\end{tabular}

To calculate the consistency of the AHP table, Formulas 4.1, 4.2, and 4.3 were used [55]. $\lambda_{\max }$ is maximum eigen value, $W_{i}$ is weighing of $i$ type of criterion or alternative. $a_{i}$ is sum of row of $i$ type of criterion or alternative. $\mathrm{CI}$ is consistency index, RI is random index, and $\mathrm{CR}$ is consistency ratio. The random index table, which was developed by Saaty [56], was used while doing CR calculation.

$$
\begin{aligned}
& \lambda_{\max }=\sum_{i=1}^{n}\left(W_{i} \cdot \sum_{i=1}^{n} a_{i}\right) \\
& \text { CI }=\frac{\lambda_{\text {max }}-\mathbf{n}}{n-1} \\
& \text { CR }=\frac{\text { CI }}{\text { RI }}
\end{aligned}
$$

\section{Assessment Results}

This section of the study includes the expert opinions about the fuel properties (criteria) used at the assessment of the alternative fuels and the assessment results of the alternative fuels at previously mentioned criteria.

\section{Expert Opinions about the Fuel Properties}

Seven academicians of a university in Istanbul, who have sea experience, indicated their opinions about the importance of fuel properties at the storage and operation of fuels on a ship. Three of the seven academicians were chief engineer, one of them was first engineer, and the remaining three were second engineers. A short questionairre was formed and asked to the experts. The questionairre was about which fuel property is more important at the storage, handling, and operation with the fuels. They gave points from 1 to 5 , to the fuel properties which are shown in Table 5 with their notations. 1 is less important while 5 is most important at the evaluation of fuel properties. All given points by the experts were summed, and the difference between each fuel property was found to determine points from 1 to 9 for AHP table. This method was also used in a previous study [4].

The expert opinion weighings are shown in Table 6. It can be seen at the table that the flashpoint and exposure rate are the most important fuel properties. The flashpoint and exposure rate get weighing of 0,315 , the auto-ignition temperature follows it with 0,207 . The flammability limits and flame speed have equal importance with 0,071 , and the density has the lowest importance with the weighing of 0,021 . 
Table 5. Fuel Property Notations for Assessment

\begin{tabular}{|l|l|}
\hline Criterion Notation & Fuel Properties \\
\hline C1 & Flashpoint \\
\hline C2 & Auto-ignition temperature \\
\hline C3 & Flammability limits \\
\hline C4 & Flame speed \\
\hline C5 & Density \\
\hline C6 & Exposure Rate \\
\hline
\end{tabular}

Table 6. Expert Opinion Weighing

\begin{tabular}{|c|c|c|c|c|c|c|c|}
\hline & C1 & C6 & C2 & C3 & C4 & C5 & W \\
\hline C1 & 1,00 & 1,00 & 2,00 & 5,00 & 5,00 & 9,00 & 0,315 \\
\hline C6 & 1,00 & 1,00 & 2,00 & 5,00 & 5,00 & 9,00 & 0,315 \\
\hline C2 & 0,50 & 0,50 & 1,00 & 4,00 & 4,00 & 9,00 & 0,207 \\
\hline C3 & 0,20 & 0,20 & 0,25 & 1,00 & 1,00 & 6,00 & 0,071 \\
\hline C4 & 0,20 & 0,20 & 0,25 & 1,00 & 1,00 & 6,00 & 0,071 \\
\hline C5 & 0,11 & 0,11 & 0,11 & 0,17 & 0,17 & 1,00 & 0,021 \\
\hline \multicolumn{7}{|c|}{$\lambda_{\max }=6,194, \mathrm{CI}=0,039, \mathrm{CR}=0,031<0,1$} \\
\hline
\end{tabular}

\section{Comparison Criterion Results}

Alternative fuels were compared with the previously mentioned criteria. The alternative fuel specifications in Table 1 were used to compare and evaluate the alternative fuels at each criterion. Same method which was used at the previous section was applied to find the relative importance between the alternative fuels, and to form AHP tables.

The flashpoint evaluation weighing of the alternative fuels are shown at Table 7. One can see from the table that the rapeseed oil is the safest alternative fuel which is followed by the soybean oil and palm oil with the weighings of $0,178,0,151$, and 0,137 , respectively. It is also seen that gaseous alternative fuels like LNG, hydrogen, and LPG are less safer than the other alternative fuels at the flashpoint evaluation.

Table 8 shows the auto-ignition temperature evaluation weighing of the alternative fuels. Ammonia, hydrogen and LNG are the top three safest alternative

Table 7. Flashpoint Evaluation Weighing of Alternative Fuels

\begin{tabular}{|l|c|c|c|c|c|c|c|c|c|c|c|c|c|c|c|}
\hline & A12 & A13 & A10 & A14 & A2 & A5 & A1 & A11 & A6 & A3 & A9 & A8 & A4 & A7 & W \\
\hline A12 & 1,00 & 2,00 & 2,00 & 2,00 & 2,00 & 3,00 & 4,00 & 5,00 & 6,00 & 6,00 & 6,00 & 8,00 & 9,00 & 9,00 & 0,178 \\
\hline A13 & 0,50 & 1,00 & 2,00 & 2,00 & 2,00 & 2,00 & 4,00 & 4,00 & 5,00 & 6,00 & 6,00 & 8,00 & 8,00 & 9,00 & 0,151 \\
\hline A10 & 0,50 & 0,50 & 1,00 & 2,00 & 2,00 & 2,00 & 4,00 & 4,00 & 5,00 & 6,00 & 6,00 & 8,00 & 8,00 & 9,00 & 0,137 \\
\hline A14 & 0,50 & 0,50 & 0,50 & 1,00 & 2,00 & 2,00 & 4,00 & 4,00 & 5,00 & 6,00 & 6,00 & 8,00 & 8,00 & 9,00 & 0,124 \\
\hline A2 & 0,50 & 0,50 & 0,50 & 0,50 & 1,00 & 2,00 & 4,00 & 4,00 & 5,00 & 6,00 & 6,00 & 8,00 & 8,00 & 9,00 & 0,112 \\
\hline A5 & 0,33 & 0,50 & 0,50 & 0,50 & 0,50 & 1,00 & 3,00 & 4,00 & 5,00 & 5,00 & 5,00 & 7,00 & 8,00 & 8,00 & 0,092 \\
\hline A1 & 0,25 & 0,25 & 0,25 & 0,25 & 0,25 & 0,33 & 1,00 & 2,00 & 3,00 & 3,00 & 3,00 & 5,00 & 6,00 & 7,00 & 0,051 \\
\hline A11 & 0,20 & 0,25 & 0,25 & 0,25 & 0,25 & 0,25 & 0,50 & 1,00 & 3,00 & 3,00 & 3,00 & 5,00 & 6,00 & 6,00 & 0,044 \\
\hline A6 & 0,17 & 0,20 & 0,20 & 0,20 & 0,20 & 0,20 & 0,33 & 0,33 & 1,00 & 2,00 & 2,00 & 4,00 & 4,00 & 5,00 & 0,030 \\
\hline A3 & 0,17 & 0,17 & 0,17 & 0,17 & 0,17 & 0,20 & 0,33 & 0,33 & 0,50 & 1,00 & 2,00 & 3,00 & 4,00 & 5,00 & 0,025 \\
\hline A9 & 0,17 & 0,17 & 0,17 & 0,17 & 0,17 & 0,20 & 0,33 & 0,33 & 0,50 & 0,50 & 1,00 & 3,00 & 4,00 & 5,00 & 0,023 \\
\hline A8 & 0,13 & 0,13 & 0,13 & 0,13 & 0,13 & 0,14 & 0,20 & 0,20 & 0,25 & 0,33 & 0,33 & 1,00 & 2,00 & 3,00 & 0,014 \\
\hline A4 & 0,11 & 0,13 & 0,13 & 0,13 & 0,13 & 0,13 & 0,17 & 0,17 & 0,25 & 0,25 & 0,25 & 0,50 & 1,00 & 2,00 & 0,011 \\
\hline A7 & 0,11 & 0,11 & 0,11 & 0,11 & 0,11 & 0,13 & 0,14 & 0,17 & 0,20 & 0,20 & 0,20 & 0,33 & 0,50 & 1,00 & 0,009 \\
\hline$\lambda_{\max }=15,046, \mathrm{CI}=0,080, \mathrm{CR}=0,051<0,1$ & & & & & & & & \\
\hline
\end{tabular}


fuels at the auto-ignition temperature evaluation with the weighing of 0,251 , 0,177 , and 0,135 , respectively. On the other hand, kerosene, jatropha oil, and waste cooking oil are three least safe alternative fuels with the weighing of $0,019,0,015$, and 0,011 , respectively.

Table 9 and 10 show lower explosive limit and upper explosive limit evaluation weighing of the alternative fuels. LEL and UEL evaluation weighing includes less number of alternative fuels for evaluation, because the vegetable oils do not have LEL and UEL values. Ammonia, methanol and LNG have higher weighing at LEL evaluation than others with $0,494,0,150$, and 0,110, respectively. Kerosene, pyrolysis oil, and LPG have lower weighing with 0,042, 0,032 , and 0,027 , respectively. Pyrolysis oil, kerosene, and LPG have higher weighing at UEL evaluation with $0,269,0,215$, and 0,181 , respectively. In contrary, hydrogen,

Table 8. Auto-ignition Temperature Evaluation Weighing of Alternative Fuels

\begin{tabular}{|l|c|c|c|c|c|c|c|c|c|c|c|c|c|c|c|}
\hline & $\mathbf{A 1}$ & $\mathbf{A 4}$ & $\mathbf{A 7}$ & $\mathbf{A 9}$ & $\mathbf{A 8}$ & $\mathbf{A 1 3}$ & $\mathbf{A 2}$ & $\mathbf{A 3}$ & $\mathbf{A 1 2}$ & $\mathbf{A 1 1}$ & $\mathbf{A 1 0}$ & $\mathbf{A 1 4}$ & $\mathbf{A 5}$ & $\mathbf{A 6}$ & $\mathbf{W}$ \\
\hline A1 & 1,00 & 3,00 & 4,00 & 5,00 & 5,00 & 5,00 & 6,00 & 7,00 & 7,00 & 7,00 & 8,00 & 8,00 & 8,00 & 9,00 & 0,251 \\
\hline A4 & 0,33 & 1,00 & 2,00 & 4,00 & 4,00 & 4,00 & 5,00 & 6,00 & 6,00 & 6,00 & 6,00 & 7,00 & 7,00 & 8,00 & 0,177 \\
\hline A7 & 0,25 & 0,50 & 1,00 & 3,00 & 3,00 & 3,00 & 4,00 & 5,00 & 5,00 & 5,00 & 6,00 & 6,00 & 6,00 & 7,00 & 0,135 \\
\hline A9 & 0,20 & 0,25 & 0,33 & 1,00 & 2,00 & 2,00 & 3,00 & 3,00 & 3,00 & 4,00 & 4,00 & 4,00 & 5,00 & 6,00 & 0,085 \\
\hline A8 & 0,20 & 0,25 & 0,33 & 0,50 & 1,00 & 2,00 & 3,00 & 3,00 & 3,00 & 3,00 & 4,00 & 4,00 & 5,00 & 6,00 & 0,075 \\
\hline A13 & 0,20 & 0,25 & 0,33 & 0,50 & 0,50 & 1,00 & 2,00 & 3,00 & 3,00 & 3,00 & 4,00 & 4,00 & 5,00 & 6,00 & 0,066 \\
\hline A2 & 0,17 & 0,20 & 0,25 & 0,33 & 0,33 & 0,50 & 1,00 & 2,00 & 2,00 & 2,00 & 3,00 & 3,00 & 4,00 & 5,00 & 0,046 \\
\hline A3 & 0,14 & 0,17 & 0,20 & 0,33 & 0,33 & 0,33 & 0,50 & 1,00 & 2,00 & 2,00 & 2,00 & 3,00 & 3,00 & 4,00 & 0,036 \\
\hline A12 & 0,14 & 0,17 & 0,20 & 0,33 & 0,33 & 0,33 & 0,50 & 0,50 & 1,00 & 2,00 & 2,00 & 3,00 & 3,00 & 4,00 & 0,033 \\
\hline A11 & 0,14 & 0,17 & 0,20 & 0,25 & 0,33 & 0,33 & 0,50 & 0,50 & 0,50 & 1,00 & 2,00 & 2,00 & 3,00 & 4,00 & 0,028 \\
\hline A10 & 0,13 & 0,17 & 0,17 & 0,25 & 0,25 & 0,25 & 0,33 & 0,50 & 0,50 & 0,50 & 1,00 & 2,00 & 2,00 & 3,00 & 0,022 \\
\hline A14 & 0,13 & 0,14 & 0,17 & 0,25 & 0,25 & 0,25 & 0,33 & 0,33 & 0,33 & 0,50 & 0,50 & 1,00 & 2,00 & 3,00 & 0,019 \\
\hline A5 & 0,13 & 0,14 & 0,17 & 0,20 & 0,20 & 0,20 & 0,25 & 0,33 & 0,33 & 0,33 & 0,50 & 0,50 & 1,00 & 3,00 & 0,015 \\
\hline A6 & 0,11 & 0,13 & 0,14 & 0,17 & 0,17 & 0,17 & 0,20 & 0,25 & 0,25 & 0,25 & 0,33 & 0,33 & 0,33 & 1,00 & 0,011 \\
\hline$\lambda_{\text {max }}=15,216, \mathrm{CI}=0,094, \mathrm{CR}=0,059<0,1$ & & & & & & & & \\
\hline
\end{tabular}

Table 9. LEL Evaluation Weighing of Alternative Fuels

\begin{tabular}{|l|c|c|c|c|c|c|c|c|c|}
\hline & A1 & A9 & A7 & A4 & A3 & A8 & A11 & A6 & W \\
\hline A1 & 1,00 & 7,00 & 7,00 & 8,00 & 8,00 & 9,00 & 9,00 & 9,00 & 0,494 \\
\hline A9 & 0,14 & 1,00 & 2,00 & 3,00 & 3,00 & 4,00 & 4,00 & 4,00 & 0,150 \\
\hline A7 & 0,14 & 0,50 & 1,00 & 2,00 & 2,00 & 3,00 & 4,00 & 4,00 & 0,110 \\
\hline A4 & 0,13 & 0,33 & 0,50 & 1,00 & 2,00 & 3,00 & 3,00 & 3,00 & 0,080 \\
\hline A3 & 0,13 & 0,33 & 0,50 & 0,50 & 1,00 & 2,00 & 3,00 & 3,00 & 0,064 \\
\hline A8 & 0,11 & 0,25 & 0,33 & 0,33 & 0,50 & 1,00 & 2,00 & 2,00 & 0,042 \\
\hline A11 & 0,11 & 0,25 & 0,25 & 0,33 & 0,33 & 0,50 & 1,00 & 2,00 & 0,032 \\
\hline A6 & 0,11 & 0,25 & 0,25 & 0,33 & 0,33 & 0,50 & 0,50 & 1,00 & 0,027 \\
\hline
\end{tabular}


methanol, and ammonia have lower weighing with $0,063,0,038$, and 0,015 , respectively.

Flame speed value of corn oil, jatropha oil, pyrolysis oil, rapeseed oil, and waste cooking oil was not found at the literature, for this reason, Table 11 does not include these alternative fuels. LNG, and LPG have higher weighing with the points of 0,239 , 0,176 , and 0,151 , respectively. Palm oil, soybean oil, and hydrogen are bottom three at the weighing table.

Table 12 shows density evaluation weighing of the alternative fuels. Hydrogen, LNG, and LPG are more safe alternative fuels than the others at the density evaluation with the weighing of $0,290,0,157$, and
0,118 , respectively, while jatropha oil, palm oil, and pyrolysis oil are less safe alternative fuels with $0,027,0,021$, and 0,012 , respectively.

Table 13 shows the exposure rate evaluation weighing of the alternative fuels. LPG and ethanol are safer than other alternative fuels at the exposure rate evaluation. There is a high difference at the weighing, which is 0,281 for LPG and ethanol, while most close one to these weighing is LNG with 0,093. Less safe alternative fuels are bio-based fuels like corn oil, jatropha oil, palm oil, rapeseed oil, soybean oil, and waste cooking oil with the weighing of 0,022 . The reason is that vapor of bio-based fuels highly affects human health when it is inhaled.

Table 10. UEL Evaluation Weighing of Alternative Fuels

\begin{tabular}{|l|c|c|c|c|c|c|c|c|c|}
\hline & A11 & A6 & A8 & A7 & A3 & A1 & A9 & A4 & W \\
\hline A11 & 1,00 & 2,00 & 2,00 & 3,00 & 3,00 & 4,00 & 5,00 & 9,00 & 0,269 \\
\hline A6 & 0,50 & 1,00 & 2,00 & 2,00 & 3,00 & 4,00 & 5,00 & 9,00 & 0,215 \\
\hline A8 & 0,50 & 0,50 & 1,00 & 2,00 & 3,00 & 3,00 & 5,00 & 9,00 & 0,181 \\
\hline A7 & 0,33 & 0,50 & 0,50 & 1,00 & 2,00 & 3,00 & 4,00 & 8,00 & 0,127 \\
\hline A3 & 0,33 & 0,33 & 0,33 & 0,50 & 1,00 & 2,00 & 4,00 & 8,00 & 0,092 \\
\hline A1 & 0,25 & 0,25 & 0,33 & 0,33 & 0,50 & 1,00 & 3,00 & 7,00 & 0,063 \\
\hline A9 & 0,20 & 0,20 & 0,20 & 0,25 & 0,25 & 0,33 & 1,00 & 6,00 & 0,038 \\
\hline A4 & 0,11 & 0,11 & 0,11 & 0,13 & 0,13 & 0,14 & 0,17 & 1,00 & 0,015 \\
\hline$\lambda_{\max }=8,463, \mathrm{CI}=0,066, \mathrm{CR}=0,047<0,1$ & & & & & \\
\hline
\end{tabular}

Table 11. Flame Speed Evaluation Weighing of Alternative Fuels

\begin{tabular}{|l|c|c|c|c|c|c|c|c|c|c|}
\hline & A1 & A7 & A8 & A3 & A9 & A6 & A10 & A13 & A4 & W \\
\hline A1 & 1,00 & 2,00 & 2,00 & 2,00 & 3,00 & 3,00 & 4,00 & 4,00 & 9,00 & 0,239 \\
\hline A7 & 0,50 & 1,00 & 2,00 & 2,00 & 2,00 & 2,00 & 3,00 & 3,00 & 9,00 & 0,176 \\
\hline A8 & 0,50 & 0,50 & 1,00 & 2,00 & 2,00 & 2,00 & 3,00 & 3,00 & 9,00 & 0,151 \\
\hline A3 & 0,50 & 0,50 & 0,50 & 1,00 & 2,00 & 2,00 & 3,00 & 3,00 & 9,00 & 0,129 \\
\hline A9 & 0,33 & 0,50 & 0,50 & 0,50 & 1,00 & 2,00 & 3,00 & 3,00 & 8,00 & 0,104 \\
\hline A6 & 0,33 & 0,50 & 0,50 & 0,50 & 0,50 & 1,00 & 2,00 & 3,00 & 8,00 & 0,086 \\
\hline A10 & 0,25 & 0,33 & 0,33 & 0,33 & 0,33 & 0,50 & 1,00 & 2,00 & 7,00 & 0,056 \\
\hline A13 & 0,25 & 0,33 & 0,33 & 0,33 & 0,33 & 0,33 & 0,50 & 1,00 & 7,00 & 0,046 \\
\hline A4 & 0,11 & 0,11 & 0,11 & 0,11 & 0,13 & 0,13 & 0,14 & 0,14 & 1,00 & 0,013 \\
\hline$\lambda_{\max }=9,432, \mathrm{CI}=0,054, \mathrm{CR}=0,037<0,1$ & & & & & \\
\hline
\end{tabular}


Table 12. Density Evaluation Weighing of Alternative Fuels

\begin{tabular}{|l|c|c|c|c|c|c|c|c|c|c|c|c|c|c|c|}
\hline & A4 & A7 & A8 & A1 & A6 & A3 & A9 & A14 & A12 & A2 & A13 & A5 & A10 & A11 & W \\
\hline A4 & 1,00 & 4,00 & 5,00 & 6,00 & 6,00 & 7,00 & 7,00 & 7,00 & 7,00 & 7,00 & 8,00 & 8,00 & 8,00 & 9,00 & 0,290 \\
\hline A7 & 0,25 & 1,00 & 2,00 & 3,00 & 4,00 & 4,00 & 4,00 & 5,00 & 5,00 & 5,00 & 5,00 & 5,00 & 5,00 & 7,00 & 0,157 \\
\hline A8 & 0,20 & 0,50 & 1,00 & 3,00 & 3,00 & 3,00 & 3,00 & 4,00 & 4,00 & 4,00 & 4,00 & 4,00 & 4,00 & 6,00 & 0,118 \\
\hline A1 & 0,17 & 0,33 & 0,33 & 1,00 & 2,00 & 2,00 & 2,00 & 3,00 & 3,00 & 3,00 & 3,00 & 3,00 & 3,00 & 5,00 & 0,078 \\
\hline A6 & 0,17 & 0,25 & 0,33 & 0,50 & 1,00 & 2,00 & 2,00 & 2,00 & 2,00 & 3,00 & 3,00 & 3,00 & 3,00 & 5,00 & 0,065 \\
\hline A3 & 0,14 & 0,25 & 0,33 & 0,50 & 0,50 & 1,00 & 2,00 & 2,00 & 2,00 & 2,00 & 2,00 & 2,00 & 3,00 & 4,00 & 0,052 \\
\hline A9 & 0,14 & 0,25 & 0,33 & 0,50 & 0,50 & 0,50 & 1,00 & 2,00 & 2,00 & 2,00 & 2,00 & 2,00 & 3,00 & 4,00 & 0,048 \\
\hline A14 & 0,14 & 0,20 & 0,25 & 0,33 & 0,50 & 0,50 & 0,50 & 1,00 & 2,00 & 2,00 & 2,00 & 2,00 & 2,00 & 4,00 & 0,039 \\
\hline A12 & 0,14 & 0,20 & 0,25 & 0,33 & 0,50 & 0,50 & 0,50 & 0,50 & 1,00 & 2,00 & 2,00 & 2,00 & 2,00 & 4,00 & 0,035 \\
\hline A2 & 0,14 & 0,20 & 0,25 & 0,33 & 0,33 & 0,50 & 0,50 & 0,50 & 0,50 & 1,00 & 2,00 & 2,00 & 2,00 & 4,00 & 0,031 \\
\hline A13 & 0,13 & 0,20 & 0,25 & 0,33 & 0,33 & 0,50 & 0,50 & 0,50 & 0,50 & 0,50 & 1,00 & 1,00 & 2,00 & 4,00 & 0,027 \\
\hline A5 & 0,13 & 0,20 & 0,25 & 0,33 & 0,33 & 0,50 & 0,50 & 0,50 & 0,50 & 0,50 & 1,00 & 1,00 & 2,00 & 4,00 & 0,027 \\
\hline A10 & 0,13 & 0,20 & 0,25 & 0,33 & 0,33 & 0,33 & 0,33 & 0,50 & 0,50 & 0,50 & 0,50 & 0,50 & 1,00 & 3,00 & 0,021 \\
\hline A11 & 0,13 & 0,14 & 0,17 & 0,20 & 0,20 & 0,25 & 0,25 & 0,25 & 0,25 & 0,25 & 0,25 & 0,25 & 0,33 & 1,00 & 0,012 \\
\hline$\lambda_{\text {max }}=15,029, \mathrm{CI}=0,079, \mathrm{CR}=0,050<0,1$ & & & & & & & \\
\hline
\end{tabular}

Table 13. Exposure Rate Evaluation Weighing of Alternative Fuels

\begin{tabular}{|l|c|c|c|c|c|c|c|c|c|c|c|c|c|c|c|}
\hline & $\mathbf{A 8}$ & $\mathbf{A 3}$ & $\mathbf{A 7}$ & $\mathbf{A 4}$ & $\mathbf{A 6}$ & $\mathbf{A 9}$ & $\mathbf{A 1 1}$ & $\mathbf{A 1}$ & $\mathbf{A 2}$ & $\mathbf{A 5}$ & $\mathbf{A 1 0}$ & $\mathbf{A 1 2}$ & $\mathbf{A 1 3}$ & $\mathbf{A 1 4}$ & $\mathbf{W}$ \\
\hline A8 & 1,00 & 1,00 & 7,00 & 8,00 & 9,00 & 9,00 & 9,00 & 9,00 & 9,00 & 9,00 & 9,00 & 9,00 & 9,00 & 9,00 & 0,281 \\
\hline A3 & 1,00 & 1,00 & 7,00 & 8,00 & 9,00 & 9,00 & 9,00 & 9,00 & 9,00 & 9,00 & 9,00 & 9,00 & 9,00 & 9,00 & 0,281 \\
\hline A7 & 0,14 & 0,14 & 1,00 & 3,00 & 3,00 & 3,00 & 4,00 & 4,00 & 4,00 & 4,00 & 4,00 & 4,00 & 4,00 & 4,00 & 0,093 \\
\hline A4 & 0,13 & 0,13 & 0,33 & 1,00 & 2,00 & 2,00 & 3,00 & 3,00 & 3,00 & 3,00 & 3,00 & 3,00 & 3,00 & 3,00 & 0,062 \\
\hline A6 & 0,11 & 0,11 & 0,33 & 0,50 & 1,00 & 2,00 & 2,00 & 2,00 & 2,00 & 2,00 & 2,00 & 2,00 & 2,00 & 2,00 & 0,044 \\
\hline A9 & 0,11 & 0,11 & 0,25 & 0,33 & 0,50 & 1,00 & 2,00 & 2,00 & 2,00 & 2,00 & 2,00 & 2,00 & 2,00 & 2,00 & 0,040 \\
\hline A11 & 0,11 & 0,11 & 0,25 & 0,33 & 0,50 & 0,50 & 1,00 & 2,00 & 2,00 & 2,00 & 2,00 & 2,00 & 2,00 & 2,00 & 0,034 \\
\hline A1 & 0,11 & 0,11 & 0,25 & 0,33 & 0,50 & 0,50 & 0,50 & 1,00 & 2,00 & 2,00 & 2,00 & 2,00 & 2,00 & 2,00 & 0,031 \\
\hline A2 & 0,11 & 0,11 & 0,25 & 0,33 & 0,50 & 0,50 & 0,50 & 0,50 & 1,00 & 1,00 & 1,00 & 1,00 & 1,00 & 1,00 & 0,022 \\
\hline A5 & 0,11 & 0,11 & 0,25 & 0,33 & 0,50 & 0,50 & 0,50 & 0,50 & 1,00 & 1,00 & 1,00 & 1,00 & 1,00 & 1,00 & 0,022 \\
\hline A10 & 0,11 & 0,11 & 0,25 & 0,33 & 0,50 & 0,50 & 0,50 & 0,50 & 1,00 & 1,00 & 1,00 & 1,00 & 1,00 & 1,00 & 0,022 \\
\hline A12 & 0,11 & 0,11 & 0,25 & 0,33 & 0,50 & 0,50 & 0,50 & 0,50 & 1,00 & 1,00 & 1,00 & 1,00 & 1,00 & 1,00 & 0,022 \\
\hline A13 & 0,11 & 0,11 & 0,25 & 0,33 & 0,50 & 0,50 & 0,50 & 0,50 & 1,00 & 1,00 & 1,00 & 1,00 & 1,00 & 1,00 & 0,022 \\
\hline A14 & 0,11 & 0,11 & 0,25 & 0,33 & 0,50 & 0,50 & 0,50 & 0,50 & 1,00 & 1,00 & 1,00 & 1,00 & 1,00 & 1,00 & 0,022 \\
\hline$\lambda_{\max }=14,890, \mathrm{CI}=0,068, \mathrm{CR}=0,043<0,1$ & & & & & & & \\
\hline
\end{tabular}

Final weighing of the alternative fuels is shown at Table 14. The weighing for LEL, UEL, and flame speed for bio-based fuels and pyrolysis oil could not be calculated due to lack of data. For this reason, final weighing of these alternative fuels were calculated without including these weighing. One can see from the Table 14 and Figure 2 that LPG has the highest final safety weighing of 0,130 . LPG has higher weighing at the UEL, flame speed, density, and the exposure rate criteria, and average weighing at autoignition temperature, which is effective at the highest final safety weighing of LPG. 
Ethanol, ammonia, and LNG follow up LPG with the final safety weighing of 0,120 , 0,116 , and 0,084 , respectively. Ethanol has a higher exposure rate, and average flame speed, LEL, and UEL, while ammonia has higher auto-ignition temperature, LEL, flame speed, and average UEL, and density.
LNG has average auto-ignition temperature, LEL, UEL, flame speed, and density.

LPG, LNG, and methanol have commercial application at the shipping industry. Hydrogen has experimental based applications. Methanol has final safety weighing of 0,053 , and hydrogen has

Table 14. Final Weighing of Alternative Fuels

\begin{tabular}{|l|c|c|c|c|c|c|c|c|}
\hline $\begin{array}{l}\text { Alternative } \\
\text { Fuels }\end{array}$ & $\begin{array}{c}\text { Flashpoint } \\
\mathbf{( 0 , 3 1 5}\end{array}$ & $\begin{array}{c}\text { Auto- } \\
\text { ignition } \\
\mathbf{( 0 , 2 0 7 )}\end{array}$ & $\begin{array}{c}\text { LEL } \\
\mathbf{( 0 , 0 3 5 5 )}\end{array}$ & $\begin{array}{c}\text { UEL } \\
\mathbf{( 0 , 0 3 5 5 )}\end{array}$ & $\begin{array}{c}\text { Flame } \\
\text { Speed } \\
\mathbf{( 0 , 0 7 1 )}\end{array}$ & $\begin{array}{c}\text { Density } \\
\mathbf{( 0 , 0 2 1 )}\end{array}$ & $\begin{array}{c}\text { Exposure } \\
\text { Rate } \\
\mathbf{( 0 , 3 1 5})\end{array}$ & $\begin{array}{c}\text { Final } \\
\text { Weighing }\end{array}$ \\
\hline Ammonia & 0,051 & 0,251 & 0,494 & 0,063 & 0,239 & 0,078 & 0,031 & 0,116 \\
\hline Corn Oil & 0,112 & 0,046 & - & - & - & 0,031 & 0,022 & 0,052 \\
\hline Ethanol & 0,025 & 0,036 & 0,064 & 0,092 & 0,129 & 0,052 & 0,281 & 0,120 \\
\hline Hydrogen & 0,011 & 0,177 & 0,080 & 0,015 & 0,013 & 0,290 & 0,062 & 0,070 \\
\hline Jatropha Oil & 0,092 & 0,015 & - & - & - & 0,027 & 0,022 & 0,040 \\
\hline Kerosene & 0,030 & 0,011 & 0,027 & 0,215 & 0,086 & 0,065 & 0,044 & 0,042 \\
\hline LNG & 0,009 & 0,135 & 0,110 & 0,127 & 0,176 & 0,157 & 0,093 & 0,084 \\
\hline LPG & 0,014 & 0,075 & 0,042 & 0,181 & 0,151 & 0,118 & 0,281 & 0,130 \\
\hline Methanol & 0,023 & 0,085 & 0,150 & 0,038 & 0,104 & 0,048 & 0,040 & 0,053 \\
\hline Palm Oil & 0,137 & 0,022 & - & - & 0,056 & 0,021 & 0,034 & 0,041 \\
\hline Pyrolysis Oil & 0,044 & 0,028 & 0,032 & 0,269 & - & 0,012 & 0,034 & 0,041 \\
\hline Rapeseed & 0,178 & 0,033 & - & - & - & 0,035 & 0,022 & 0,071 \\
\hline Oil & 0,151 & 0,066 & - & - & 0,046 & 0,027 & 0,022 & 0,072 \\
\hline Soybean Oil & 0,124 & 0,019 & - & - & - & 0,039 & 0,022 & 0,051 \\
\hline WCO & & & & &
\end{tabular}

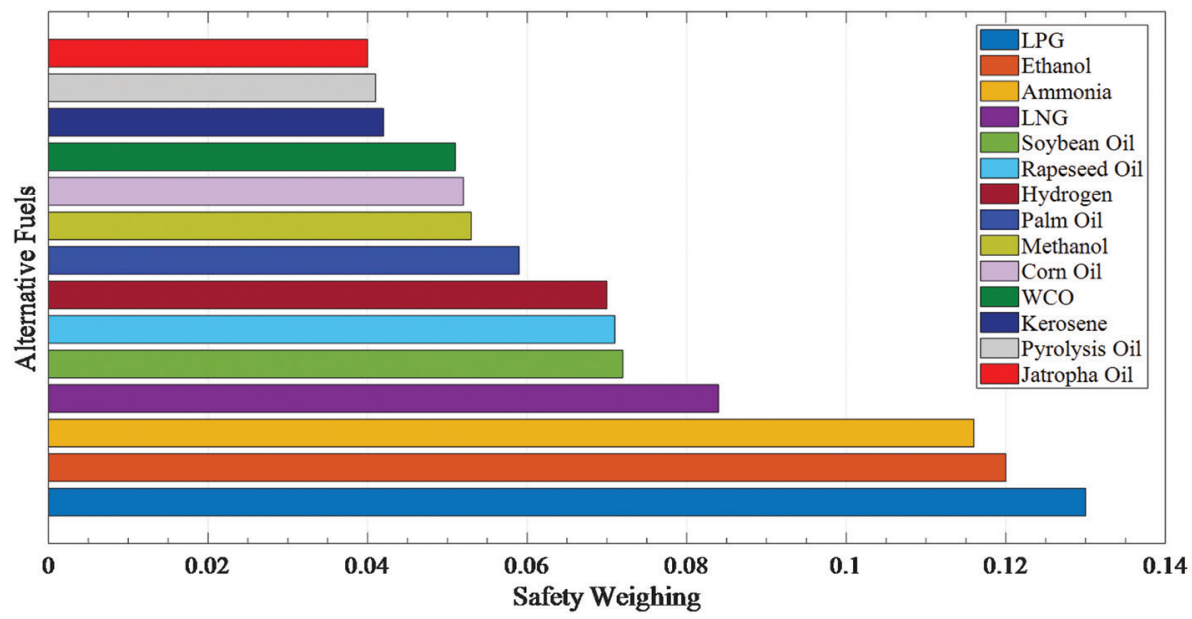

Figure 2. Graph of Onboard Safety Assessment Result 
0,070 . Low weighing values of flashpoint, auto-ignition temperature, UEL, density, and exposure rate of methanol, and low weighing values of flashpoint, LEL, UEL, and flame speed of hydrogen are the reason of low level of final safety weighing of these alternative fuels. Remaining alternative fuels are bio-based fuels, kerosene, and pyrolysis oil. These alternative fuels have lower final safety weighing between 0,052 and 0,040 .

Lower final safety weighing does not prevent the alternative fuels to be used on ships by the engine manufacturers and ship builders. The advantage of combustion characteristic with lower emissions is attractive for the shipping industry, and the onboard applications have been made with the extra safety precautions and systems, which also means higher initial and operational costs.

\section{Conclusion}

The safety evaluation method was formed to assess the alternative fuels by focusing on shipboard handling, storage, and crew health. Recent trend alternative fuels and possible alternative fuels for the future were the assessed fuels. The study aimed to show the safety ranking of the trend alternative fuels and possible ones in the future. Fourteen alternative fuels were used in the safety evaluation.

The criteria were determined to form the safety evaluation method and assess the alternative fuels. These criteria were flashpoint, auto-ignition temperature, flammability limits, flame speed, density, and exposure limit. The criteria weighing were determined by the taken opinions of seven experts who are academicians and have sea experience. The experts determined the weighing of flashpoint and exposure rate as 0,315 , auto-ignition temperature as 0,207 , flammability limits and flame speed as 0,071, and density as 0,021 . The assessment of alternative fuels was done by comparing the physicochemical properties of the alternative fuels. The AHP method was used both to determine the criteria weighing, and to compare alternative fuels.

According to the criteria assessment results, rapeseed oil had the highest weighing at the flashpoint criterion with 0,178 . Ammonia got the highest weighing at the auto-ignition temperature with 0,251 . Due to lack of information about the LEL and UEL of bio-based fuels, only eight alternative fuels could be assessed at this criterion. Ammonia got 0,494 at the LEL, and kerosene got 0,215 at the UEL as the highest weighing. In addition, there was lack of information about the flame speed of some alternative fuels, for this reason only nine alternative fuels could be assessed at this criterion. Ammonia had the highest weighing with 0,239 . Hydrogen had the highest weighing at the density criterion with 0,290 , and ethanol and LPG had the highest weighing at the exposure rate criterion with 0,281 .

The final safety assessment results showed that LPG got the highest final safety weighing with 0,130. Ethanol and ammonia followed it with 0,120 and 0,116, respectively. LNG and methanol are trend alternative fuels with LPG for shipping industry. LNG had 0,084, and methanol had 0,053 as the final safety weighing.

There were limitations at the study. Some alternative fuels did not have the flammability limits, and the flame speed of some alternative fuels were not found in the literature. Therefore, these fuels could not be assessed at these criteria. The exposure limit of jatropha oil, palm oil, and WCO were not found in the literature. It was assumed that these fuels have same exposure limit with the other vegetable oils. The expert number could be higher, and experts could be selected from the safety experts.

The study aimed to determine the safety rankings of the alternative fuels, which have been used and can be used in the future. 
There has not been any previous study, which includes a wide range of alternative fuels for the purpose of the assessment of the fuels from the aspect of shipboard safety. It is first time to include some alternative fuels in a marine-based study. The alternative fuels with lower weighing do not mean that these fuels cannot be used on ships. However, it means more safety systems have to be applied on ships, and higher safety precautions have to be taken while the storage of these fuels and the operation with the fuels. It causes higher initial and operational costs. In addition to this, extra safety equipment increases the weight of the ship, and reduces cargo capacity of the ship. The ship builders/operators have to consider these drawbacks of the alternative fuels before selecting for their ship. Next study can be the combination of shipboard safety assessment results and cost-benefit assessment of alternative fuels.

\section{References}

[1] DNV GL: The Future of Shipping, Høvik, 04.2014.

[2] International Maritime Organization, International Convention for the Safety of Life at Sea. Access Date: 18 September 2017. http://www. imo.org/en/About/conventions/ lis tof conventions / pages / international-convention-for-thesafety-of-life-at-sea-(solas),-1974. aspx.

[3] International Maritime Organization, Gas and low-flashpoint fuels code adopted by IMO. Access Date: 18 September 2017. http:// www.imo.org/en/mediacentre/ pressbriefings/pages/26-msc-95ends.aspx.

[4] Deniz, C., Zincir, B. (2016). Environmental and economical assessment of alternative marine fuels. Journal of Cleaner Production, 113(2016)438-449.
[5] Gu, Y., Zhang, C. (2014). Alternative energies or fuels for future deep sea container shipping. Master degree thesis, University of Gothenburg, School of Business, Economics and Law.

[6] Mansson, S. (2017). Prospects for renewable marine fuels, a multicriteria decision analysis of a alternative fuels for the maritime sector. Master thesis, Industrial Ecology, Chalmers University of Technology.

[7] Hossain, A. K., Davies, P. A. (2010). Plant oils as fuels for compression ignition engines: a technical review and life-cycle analysis. Renewable Energy, 35(2010)1-13.

[8] Google Scholar, Alternative fuel research number, 17 March 2017.

[9] University of Nebraska Lincoln. Safe Operating Procedure. Hazards of Flammable Gases, Liquids \& Aerosols \& Risk Minimization. Access Date: 8 November 2017. https://ehs.unl. edu/sop/s-hazards_flam_gases_liq_ aeros_risk_min.pdf.

[10] Reiter, A. J., Kong, S. (2011). Combustion and emission characteristics of compressionignition engine using dual ammoniadiesel fuel. Fuel 90(2011)87-97.

[11] Praxair. Ammonia Material Safety Data Sheet. Access Date: 11 November 2017. http://www.praxair.com/-/ media/documents/sds/ammonianh3-safety-data-sheet-sds-p4562. pdf?la=en.

[12] Nozari, H., Karabeyoglu, A. (2014). Chemical kinetics study of combustion characteristics of ammonia-air mixtures under high pressure lean conditions. https://nh3fuel.files. wordpress.com/2014/10/nh3fa2014-hadi-nozari-arif-karabeyoglu. pdf. 
[13] Hossain, A. K., Davies, P. A. (2010). Plant oils as fuels for compression ignition engines: a technical review and lifecycle analysis. Renewable Energy, 35(2010)1-13.

[14] Sidibe, S. S., Blin, J., Vaitilingam, G., Azoumah, Y. (2010). Use of crude filtered vegetable oils as a fuel in diesel engines state of the art: literature review. Renewable and Sustainable Energy Reviews, 14(2010)2748-2759.

[15] Hankinson Renewable Energy. Material Safety Data Sheet Corn Oil. Access Date: 1 November 2017. http://corporate. murphyusa.com/content/documents/ MSDS_PDFs/CORN_OIL_Murphy_Oil_ HRE_-_CAN_US_V4.1English_US.pdf.

[16] Science Lab Chemicals \& Laboratory Equipments. Corn Oil Material Safety Data Sheet. Access Date: 20 November 2017. http://www.sciencelab.com/ msds.php?msdsId=9927139.

[17] Parthasarathi, R., Gawri, S., Saravanan, C. G. (2014). Effects of ethanol-diesel emulsions on the performance, combustion and emission characteristics of DI diesel engine. American Journal of Applied Sciences, 11(4):592-600,2014.

[18] Labeckas, G., Slavinskas, S., Mazeika, M. (2014). The effect of ethanol-dieselbiodiesel blends on combustion, performance and emissions of a direct injection diesel engine. Energy Conversion and Management, 79(2014)698-720.

[19] Science Lab Chemicals \& Laboratory Equipment. Material Safety Data Sheets Ethyl Alcohol 200 Proof. Access Date: 10 November 2017. https://www.sciencelab.com/msds. php?msdsId=9923955.

[20] Jhang, S. R., Chen, K. S., Lin, S. L., Lin, Y. C., Cheng, W. L. (2016). Reducing pollutant emissions from a heavyduty diesel engine by using hydrogen additions. Fuel 172(2016)89-95.
[21] National Research Council. (2008). 7 Hydrogen. Emergency and Continuous Exposure Guidance Levels for Selected Submarine Contaminants: Vol. 2. Washington, DC: The National Academies Press. doi: 1017226/12032, pp.154.

[22] Nasim, M. N., Yarasu, R. B., Sarda, R. H. (2013). Experimental investigation on compression ignition engine powered by preheated neat jatropha oil. Journal of Petroleum Technology and Alternative Fuels, Vol 4(7), pp.119124, doi:10.5897/JPTAF 10.004.

[23] Science Lab Chemicals \& Laboratory Equipment. Material Safety Data Sheet Kerosene. Access Date: 14 November 2017. http://www.sciencelab.com/ msds.php?msdsId=9924436.

[24] Aydin, H., Bayindir, H., Ilkiliç, C. (2010). Emissions from an engine fueled with biodiesel-kerosene blends. Energy Sources, Part A: Recovery, Utilization, and Environmental Effects, 33:2,130137.

[25] Tesoro. (2014). Kerosene Material Safety Data Sheet. Access Date: 23 November 2017. https://tsocorpsite. files.wordpress.com/2014/08/ kerosene.pdf.

[26] Wu, Y. (2016). Experimental investigation of laminar flame speeds of kerosene fuel and second generation biofuels in elevated conditions of pressure and preheat temperature. Chemical Physics, INSA de Rouen.

[27] PGW. Liquefied Natural Gas (LNG) Material Safety Data Sheet. Access Date: 20 November 2017. https:// www.pgworks.com/uploads/pdfs/ LNGSafetyData.pdf.

[28] Lukoil. LNG Material Safety Data Sheet. Access Date: 20 November 2017. http: / / en.lukoil.com.tr/Upload/ Docs/LNG\%20(MSDS)-EN.pdf. 
[29] OnGas. LPG Material Safety Data Sheet. Access Date: 18 November 2017. https://www.ongas.co.nz/Assets/ OnGas\%20 Material\%20Safety\%20 Data\%20Sheet\%200CT\%202014.pdf.

[30] Contact Energy. LPG Material Safety Data Sheet. Access Date: 18 November 2017. https://contact.co.nz/-/media/contact/ pdfs/residential/reference-guides/ safety- data-sheet.ashx?la=en\&hash $=5 \mathrm{~A}$ C0B371B 71A873D64668E4BFE DA04246590501C.

[31] Shell. LPG Material Safety Data Sheet. Access Date: 18 November 2017. http://www.shell.com/content/dam/ shell-new/local/corporate/tradingshipping/downloads/msds/in-country/ singapore-sietco/lpg-lpg---sietco---en. pdf.

[32] Liao, S. Y., Jiang, D. M., Cheng, Q., Gao, J., Huang, Z. H., Hu, Y. (2005). Correlations for laminar burning velocities of liquefied petroleum gas-air mixtures. Energy Conversion and Management, 46(2005)3175-3184.

[33] Science Lab Chemicals \& Laboratory Equipment. Material Safety Data Sheet Methyl Alcohol. Access Date: 11 November2017.http://www.sciencelab. com/msds.php?msdsId=9927227.

[34] Science Lab Chemicals \& Laboratory Equipment. Material Safety Data Sheet Palm Oil. Access Date: 5 November 2017. http://www.sciencelab.com/msds. php?msdsId=9926383.

[35] Chong, C. T., Hochgreb, S. (2011). Measurements of laminar flame speeds of liquid fuels: Jet-A1, diesel, palm methyl esters and blends using particle imaging velocimetry (PIV). Proceedings of the Combustion Institute, 33(2011)979986.

[36] Chevron Phillips Chemical Company. Heavy Pyrolysis Oil Material Safety Data Sheet. Access Date: 15 November 2017. http://www.cpchem.com/ msds/100000014923_SDS_US_EN.PDF.
[37] CIRAD. Bio-oil Material Safety Data Sheet. Access Date: 15 November 2017. http://www.pyne.co.uk/ Resources/user/docs/CIRAD_MSDSFinal.pdf.

[38] Science Lab Chemicals \& Laboratory Equipments. Naphthalene Material Safety Data Sheet. Access Date: 15 November 2017. http:// www.sciencelab.com/msds. php?msdsId=9927671.

[39] Spectrum Chemical. Rapeseed Material Safety Data Sheet. Access date: 21 November 2017. https:// www.spectrumchemical.com/MSDS/ R2221.PDF.

[40] Buda-Ortins, K. (2010). Auto-ignition of cooking oils. University of Maryland, Department of Fire Protection Engineering, 19.05.2010.

[41] Science Lab Chemicals \& Laboratory Equipments. Soybean Oil Material Safety Data Sheet. Access Date: 21 November 2017. http:// www.sciencelab.com/msds. php?msdsId=9925064.

[42] Gomez-Meyer, J. S., Gollahalli, S. R., Parthasarthy, R. N., Quiroga, J. E. (2012). Laminar flame speed of soy and canola biofuels. C.T.F Cienc. Technol. Futuro vol.4 no.5 Bucaramanga, January/June 2012.

[43] Natural Sourcing Specialists in Cosmeceutical Ingredients. Material Safety Data Sheet Soybean Oil. Access Date: 6 November 2017. https://www. naturalsourcing.com/downloads/ msds/MSDS_Soybean_Oil.pdf.

[44] ConAgra Foods. Soybean Material Safety Data Sheet. Access Date: 21 November 2017. http:// sds.chemtel.net/webclients / cheneybrothers/116009SDS.pdf.

[45] Bioils S.A. Material Safety Data Sheet Used Cooking Oil. Access Date: 6 November 2017. http://www.bioils. com.co/descargas/MSDS.pdf. 
[46] Kathirvel, S., Layek, A., Muthuraman, S. (2016). Exploration of waste cooking oil methyl esters (WCOME) as fuel in compression ignition engines: a critical review. Engineering Science and Technology, an International Journal, 19(2016)1018-1026.

[47] Wikipedia, Flashpoint, Access Date: 17.03.2018. https://en.wikipedia. org/wiki/Flash_point.

[48] Wikipedia,Auto-ignition Temperature, Access Date: 17.03.2018, https:// en.wikipedia.org/wiki/Autoignition_ temperature.

[49] Wikipedia, Flammability Limits, Access Date: 17.03.2018, https:// en.wikipedia.org/wiki/Flammability_ limit.

[50] Wikipedia, Flame Speed, Access Date: 17.03.2018, https://en.wikipedia. org/wiki/Flame_speed.

[51] American Conference of Governmental Industrial Hygienists. Access Date: 25 September 2017. http://www. acgih.org/tlv-bei-guidelines/policiesprocedures-presentations.

[52] Saaty, T. L. (1980). The Analytic Hierarchy Process: Planning, Priority Setting, and Resource Allocation, McGraw-Hill, New York.

[53] Winebrake, J. J., Creswick, B. P. (2003). The future of hydrogen fueling systems for transportation: an application of perspective-based scenario analysis using the analytic hierarchy process. Technological Forecasting \& Social Change, 70(2003)359-384.

[54] Ren, J., Sovacool, B.K. (2015). Prioritizing Low-carbon Energy Sources to Enhance China's Energy Security. Energy Conversion and Management, 92(2015)129-136.

[55] Render, B., Stair, R. M. (1999). Quantitative Analysis for Management, 7th Edition. Pearson. Pp. 522-529.
[56] Saathy, T. L., Tran, L. T. (2007). On the invalidity of fuzzifying numerical judgments in the analytic hierarchy process. ISAHP 2007, Vina del Mar, Chile, August 3- 6, 2007. 